\title{
Köpenhamns uppkomst
}

\section{Om nätverk och aktörer i det tidigmedeltida Östdanmark}

Af Hanna Dahlström

De senaste årens arkeologiska undersökningar har gett en helt ny förståelse för sammanhanget kring Köpenhamns uppkomst och tidiga utveckling. Främst Metro Cityring-utgrävningarna kring Rådhuspladsen mellan 2011 och 2018 har bidragit med information om stadens ålder och utbredning. ${ }^{1}$ De har inte minst, på allvar motbevisat en seglivad historieskrivning om biskop Absalon som Köpenhamns grundläggare.

Resultaten från utgrävningarna visar på, att den äldsta bebyggelsen växte fram från 1000-talets första hälft, och att området där Rådhuspladsen nu ligger, har hyst en kyrka, med tillhörande kyrkogård, bebyggelse och hantverksaktiviteter. ${ }^{2}$ Strax öster om Rådhuspladsen, har ytterligare en kyrka - St. Clemens kyrka och tillhörande kyrkogård, legat. Området mellan Rådhuspladsen och dagens Gammeltorv har utgjort ett kärnområde i den äldsta staden, och härifrån har bebyggelsen vuxit, främst mot öster, för att under högmedeltid likna den vi känner från kartor från medeltidens slut (figur 1).

Förutom ny kunskap om stadens ålder och utbredning, har utgrävningarna på Rådhuspladsen möjliggjort en mer konkret diskussion kring de aktörer, nätverk samt ekonomiska och politiska intressen som bidragit till stadens uppkomst och inte minst, lagt grunden till dess framtida blomstring. I detta sammanhang träder stadens läge vid Öresund fram som en avgörande faktor. ${ }^{3}$

\section{Havn}

Den äldsta kända benämningen på Köpenhamn, Havn (från 1186) avslöjar stadens huvudsakliga funktion och orsaken till dess uppkomst och framgång genom många århundraden. I en tid då stora delar av handel och transport skedde över vatten, utgjorde Havn en naturlig samlingspunkt för de varor och människor som skulle färdas över sundet till Skåne. Vi befinner oss i 1000-talets första hälft, och kungamakten i Danmark är i färd med att konsolidera riket. De östra provinserna, Skåne, Halland och Blekinge, låg längst bort från kungaättens centralområden i Jylland, och det krävdes extra insatser för att samla också dessa under kungens överhöghet.

Det andra namnet som användes på Havn i medeltida skriftliga källor - Købmannahavn - vittnar om en tidig, merkantil funktion. Landskapet omkring Köpenhamn har ända sedan förhistorisk tid varit en rik jordbruksbygd, och ortnamnen, liksom skattfynd från yngre järnålder vittnar om ett område med koncentrationer av agrara resurser och rikedomar. ${ }^{5}$ Att de släkter som bebodde de storgårdar som funnits spridda i regionen, hade behov av en handelsplats och en hamn för distribution av agrara varor, är sannolikt. Platsen där Havn, eller Købmannahavn, växte fram är en av få djuphamnar på Själlands östkust. Den är dessutom skyddad bakom ett antal mindre öar, där Strandholmen och Bremerholm utgör ett par av de större. Läget har alltså varit helt avgörande för den bebyggelse som växte fram, och för de aktiviteter som varit grunden för dess existens.

Hanna Dahlström, arkæolog og museumsinspektør, Ph.d,, Købehavns Museum 


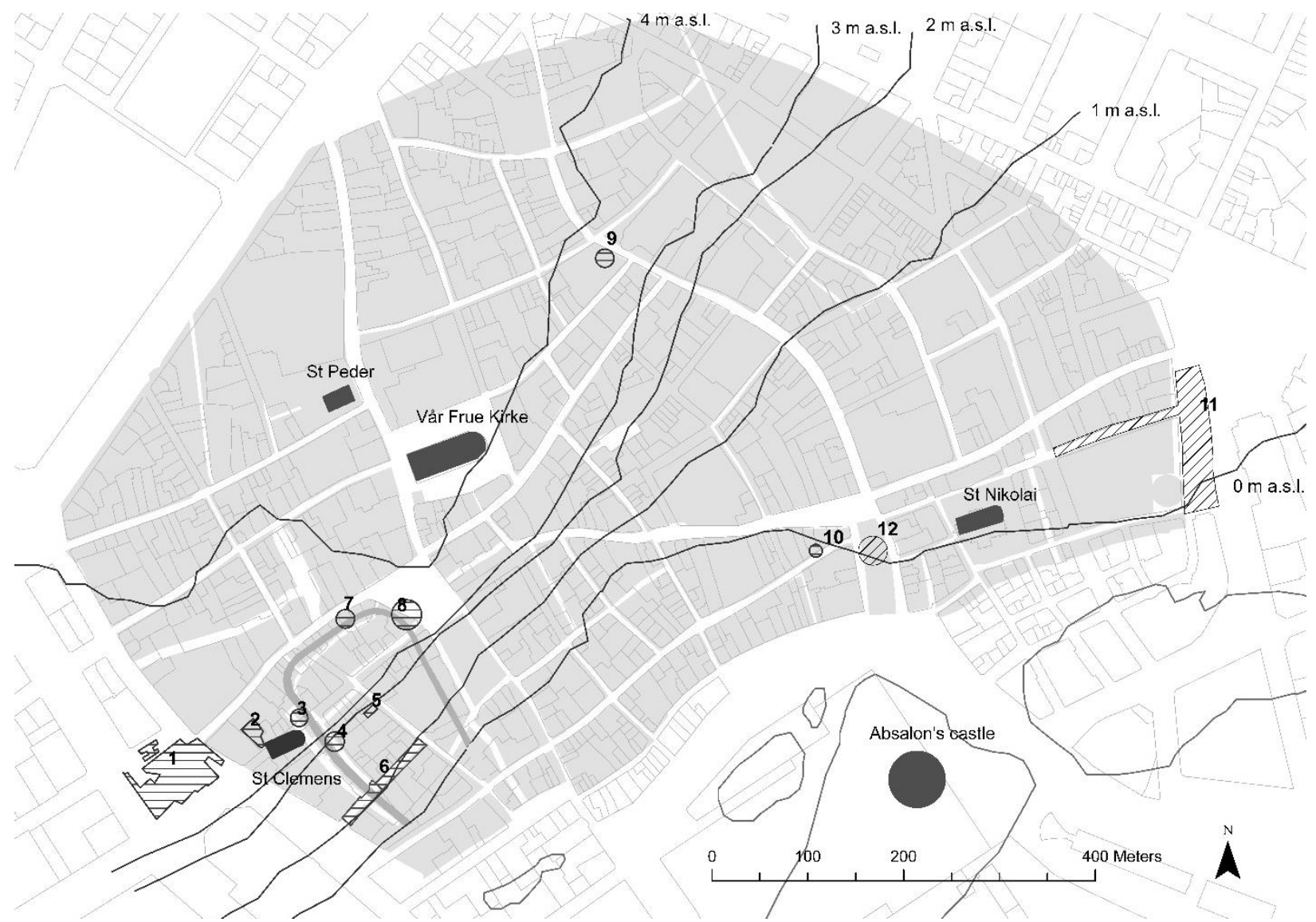

Rekonstruktion av det senmedeltida Köpenhamn (grå markering) som visar de äldre, samt nyare arkeologiska upptäckterna som bidragit med information om det tidigmedeltida Köpenhamn (siffror 1-12). Den tidigmedeltida strandlinjen samt topografiska kurvor är markerade. Det moderna gatunätet ses som bakgrund. 1: Rådhuspladsen KBM 3827 (2011-12); KBM 4286 (2017-18); 2: Sankt Clemens/Vestergade 29-31 KBM 3621 (2008); 3: Frederiksberggade 30 (AA 72 (1984); 4: Mikkel Bryggers Gade 11-13 KBM 250 (1989); 5: Kattesundet 10 KBM 4088 (2015); 6: Nørregade m.fl (Lavendelstræde).KBM 4022 (2015); 7: Vestergade 7 AA 104 (1987); 8: Gammeltorv/Nytorv/ Frederiksberggade. (1909); 9: Regensen KBM 3824 (2012); 10: Amagertorv 7/Læderstræde 8 KBM 2822 (2003); 11: Kongens Nytorv KBM 1410/1910 (1996), KBM 3829 (2010-16), 12: Højbro Plads, KBM 1213 (1994).

\section{Betydelsen av de två kyrkorna}

Förekomsten av två kyrkor redan under 1000-talet visar på att Havn varit mer än en landsby eller ett säsongsmässigt fiskeläge. I perioden fram till 1100-talet slut, innan sockensystemet reglerade kyrkobyggandet, byggde stormän med ekonomiska resurser ett okänt antal privatkyrkor i Danmark. De flesta av dessa lades ner redan under tidig medeltid. ${ }^{6}$ Kyrkogården på Rådhuspladsen påträffades första gången 2011, då 11 gravar med in situ-bevarade skelett samt människoben i gravfyllningarna, gav en föraning om att det här en gång i tiden funnits en betydligt större kyrkogård (figur 2).

Gravarna befann sig nämligen helt i den ytterst nordvästra delen av undersökningsområdet, och det var tydligt i jordprofilerna mot nord och mot väst, att det fanns fler gravar i de riktningarna. ${ }^{7}$

Vid utgrävningar i anslutande områden under 2017-18 fann Köpenhamns Museum ytterligare 70 gravar med in situ-bevarade skelett, en del av ett kyrkofundament samt en klockstöpningsgrop. ${ }^{8}$ Det var ett faktum att kyrkogården på Rådhuspladsen varit av betydande storlek. 14C-dateringen av de 11 gravarna funna 2011 visar på att kyrkogården endast användes under en begränsad period under 1000-talet. Den korta användningstiden bekräftas av att gravarna endast låg i upp till tre stratigrafiska lager, och de flesta endast i ett lager (se figur 2). Det faktum att kyrkan på 
Rådhuspladsen är helt okänd från skriftliga källor understryker den tidiga dateringen. Det ligger närmast tillhands att se kyrkan på Rådhuspladsen som en privatkyrka byggd av en av de stormannafamiljer som hade ekonomiskt engagemang i handeln och transporten i Havns tidiga skede. ${ }^{14} \mathrm{C}$-dateringar av gravar från St. Clemens kyrkogård, belägen 150 meter öster om kyrkan på Rådhuspladsen, tyder på att även denna kyrka har sitt ursprung i 1000-talet. ${ }^{9}$ Ett $700 \mathrm{~m}^{2}$ stort område i kyrkogårdens norra del undersöktes 2008 av Københavns Museum. Mer än 1000 gravar i upp till sju stratigrafiska nivåer vittnar om att kyrkogården använts under hela medeltiden. Kyrkogården uppvisar en variation i gravritualer som inte fanns på kyrkogården på Rådhuspladsen. ${ }^{10}$ Dessutom gjordes en del föremålsfynd i gravarna.

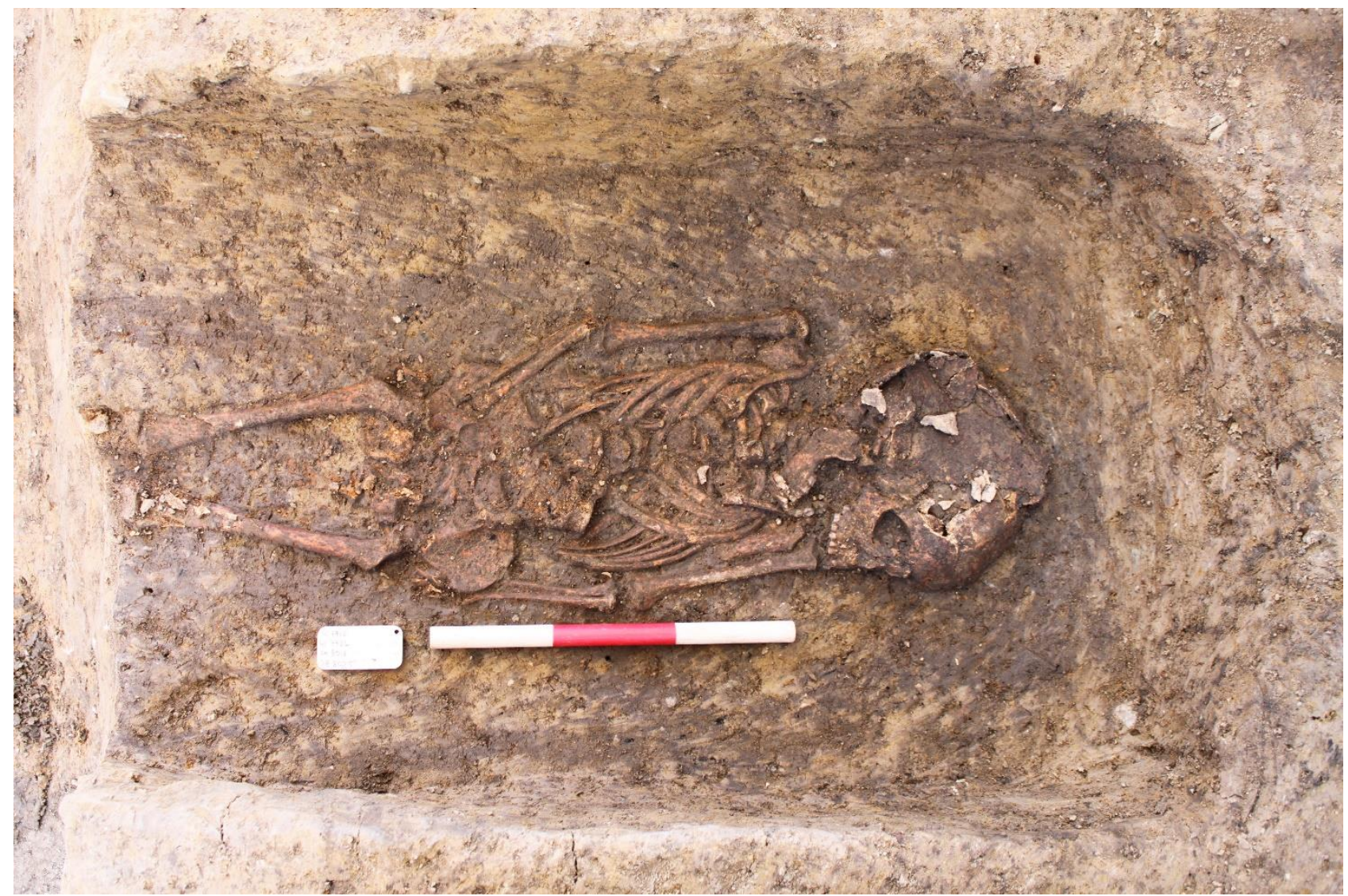

En av gravarna som upptäcktes på Rådhuspladsen 2011. Den begravda individen var ett barn, ca 5 år gammalt. Det fanns lösa ben i gravfyllningen, vilket indikerar närvaro av äldre, störda gravar.

Ett ovanligt fynd i form av ett myntsmycke från en barngrav bekräftar dateringen till 1000-talet, som ${ }^{14} \mathrm{C}$-analyserna indikerar. (se figur 3). Myntsmycket efterliknar ett engelskt mynt, slaget under kung Aethelred, och som tillverkades 978-1017. ${ }^{11}$ Denna typ av myntsmycke tillverkades i Lund under tidigt 1000 -tal. ${ }^{12}$ Det fanns ett antal kyrkor vigda åt St. Clemens runt omkring i Norden och i England, med de flesta i Danmark. ${ }^{13}$ Många av St. Clemenskyrkorna tros ha byggts omkring 1000talets mitt, och de kopplas ofta till kungamaktens konsolidering samt kopplingen mellan Danmark och England under den period då danska kungen också var kung över delar av England. Med detta som bakgrund är det troligt att St. Clemenskyrkan i Köpenhamn uppfördes i mitten av 1000-talet på kungligt initiativ. ${ }^{14}$ 


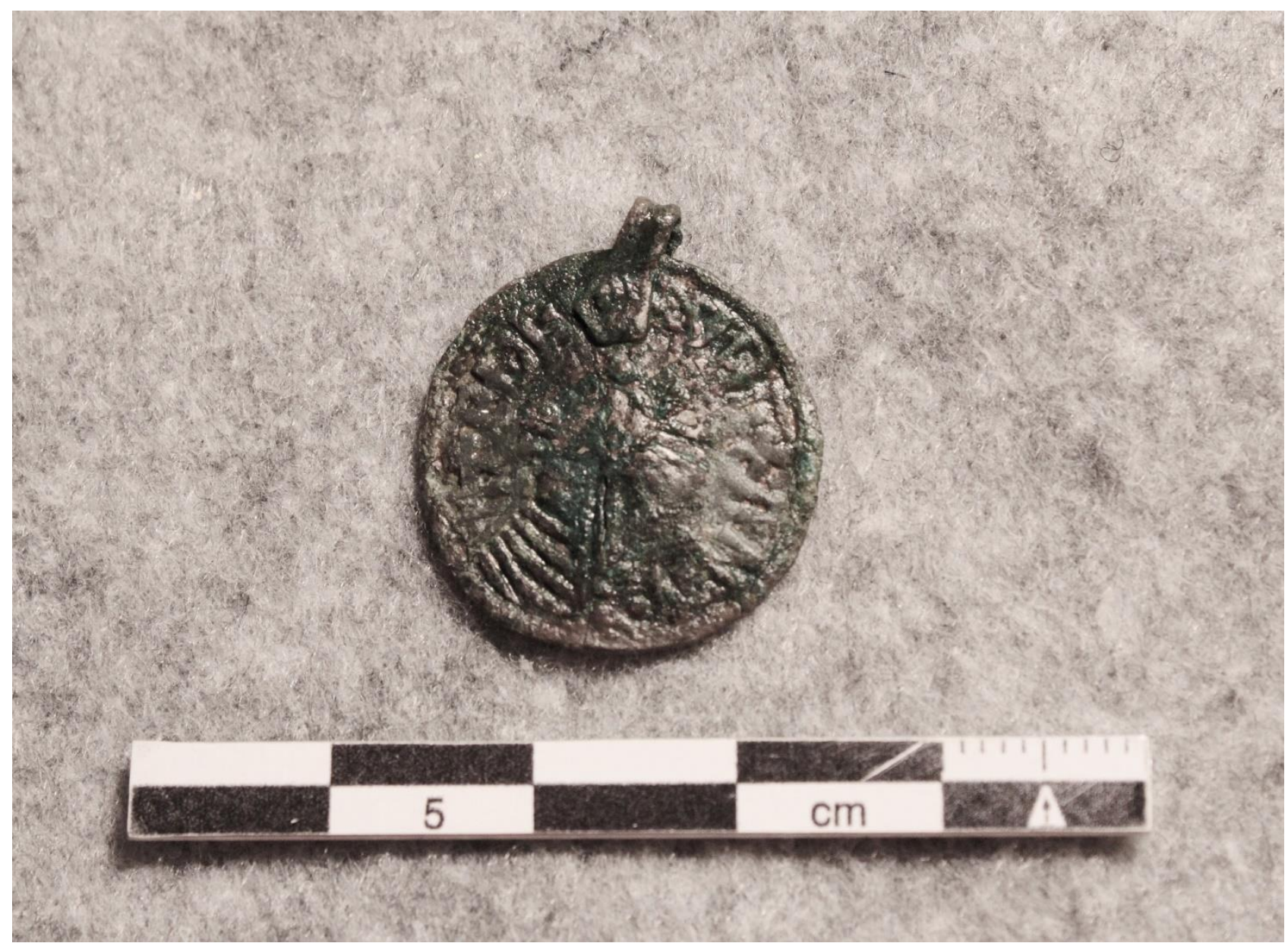

Myntsmycke i kopparlegering, funnet på bröstet av ett gravlagt barn på St. Clemens kyrkogård. Det dateras till 1000talets första årtionden.

Detta scenario, med en privat kyrkobyggare på Rådhuspladsen, och en något senare kunglig närvaro i form av St. Clemenskyrkan, är lätt att infoga i den tolkning av stadens ursprung och tidiga framväxt som skissats ovan. De ekonomiska och politiska gynnsamma förutsättningar som läget haft, har samlat flera mäktiga aktörer i Havn, och dessa har bidragit till att forma den stad som började växa fram.

\section{Fiskeri}

I historieskrivningen kring Köpenhamns uppkomst har fiskeri ofta framhållits som den främsta orsaken till uppkomsten av Havn samt som den viktigaste försörjningsmöjligheten för de människor som bosatte sig eller vistades där. ${ }^{15}$ En ofta framförd teori om Havn har länge varit, att det hade sitt ursprung $\mathrm{i}$ en återkommande, säsongsbetonad fiskemarknad. Om man ser till den information om fiskeri som framkommit genom senare års arkeologiska utgrävningar, kan detta dock inte omedelbart bekräftas. På Metro Cityring-utgrävningarna på Rådhuspladsen och på Kongens Nytorv har stora mängder fiskben från medeltida kulturlager omhändertagits och analyserats av specialister. ${ }^{16}$ Fiskbenen påträffades främst i gropar och brunnar, som sekundärt använts till att deponera avfall. Tack vare vattensållning av jord från dessa fyllningar kunde även mycket små ben, till exempel från sill, registreras. Det gör fiskbensmaterialen från de båda utgrävningarna till mycket goda källmaterial för att diskutera fiskens roll för det medeltida Köpenhamn. För perioden tidig medeltid är det Rådhuspladsutgrävningen som bidragit med klart mest information. Det finns enligt de analyser som gjorts på detta material inget som tyder på fiskbenen är rester efter annat än 
måltider, alltså konsumtion av de människor som bott på platsen. Mängd och fördelning av bevarade ben från olika delar av fiskskelettet visar inga indikationer på bearbetning eller förvaring av fisk inför försäljning eller distribution i större skala.

Vid jämförelser av fiskbensmaterial mellan Rådhuspladsen och den närbelägna landsbyen Tårnby, framkommer dock en del intressanta skillnader i konsumtionsmönster. Från Rådhuspladsen finns lämningar av 27 fiskarter från perioden 1000-t - 1300-t, medan det från Tårnby finns 17 arter. ${ }^{17} \mathrm{I}$ Tårnby dominerade sill fullständigt, med $77 \%$ av samtliga ben från sill, med torsk på andra plats med 17\%. Fiskkonsumtionen i Köpenhamn har, av materialet från Rådhuspladsen att döma, varit mer varierad, med $45 \%$ sill och $38 \%$ torsk. Efter sill och torsk kommer flatfisk och ål (med $6 \%$ vardera på Rådhuspladsen, och 3\% resp. 2\% i Tårnby). Skillnader i fiskbensmaterialen tyder på olika konsumtionsmönster, som kan förklaras med att staden och landsbyen haft olika tillgång till marknader. ${ }^{18}$ Invånarna i Köpenhamn har haft en mer varierad fiskkost, något som högst troligt beror på att fisk har saluförts i staden, även om man inte kan säga att det varit en dominerande näring utifrån det tillgängliga arkeologiska materialet.

\section{Järnsmide}

Som något helt nytt för Köpenhamns del, påträffades det på Rådhuspladsen relativt omfattande lämningar av smidesavfall från tidig och högmedeltid. Sammanlagt samlades över 500 kr järnslagg in från gropar, stora utjämningslager samt vägbeläggningar, från perioden 1050-1350 (se figur 4). ${ }^{19}$ Förutom slagg påträffades bitar av ugnsväggar, samt små smidespartiklar som bildas under olika delar av järnframställningsprocessen. Dessa små partiklar har knappast färdats lång väg, vilket ses som en stark indikation på att smidesverkstäder funnits på platsen.

Även det faktum att smidesavfallet deponerats i gropar, varvat med hushållsavfall, tyder på att det föregått på platsen, som en del av det vardagliga livet. Spridningen av smidesavfallet över hela undersökningsområdet på ca $2000 \mathrm{~m}^{2}$, samt de metallurgiska analyserna som gjordes på delar av materialet, indikerar att det rör sig om ett antal verkstäder med olika typer av produktion. ${ }^{20}$ Det har förekommit både förädling av järnråvara (primärsmide) samt smide av föremål (sekundärsmide). De föremål som producerats har varit av enkel typ, såsom spikar och beslag.

Skalan på smidet ökar med tiden, och det sker också en övergång från mestadels sekundärt till primärt smide. En intressant aspekt av materialets karaktär är att det i flera fall uppvisar en överhettning av järnet i smidesprocessen. Det är inget man har eftersträvat, då överhettning gör järnets egenskaper sämre. Det kan här vara spår av ett lärlingssystem som ses, då det torde vara oerfarna smeder som gjort sådana misstag. Ännu mer intressant är att den metallurgiska analysen pekar på att den mesta av järnråvaran hade sitt ursprung i dagens södra Sverige. Kemiska analyser av partiklar i slaggen visar på stora likheter med järnmalm från området som sträcker sig från Halland, norra Skåne, södra Småland och Blekinge i dagens Sverige.

Ser man till den totala mängden slagg som insamlats från Rådhuspladsen kan den tyckas liten, med tanke på att den tidsmässigt är spridd över ca 300 år. Jämfört med de flesta andra danska städer är det dock ett relativt stort material. Med de främsta undantagen i nuvarande skånska orter som Lund, Tommarp och Vä, brukar mängden insamlad slagg från danska urbana kontexter vara blygsam. Järnhantverkets roll i de danska medeltida städerna är därför förhållandevis outforskat. ${ }^{21}$ 


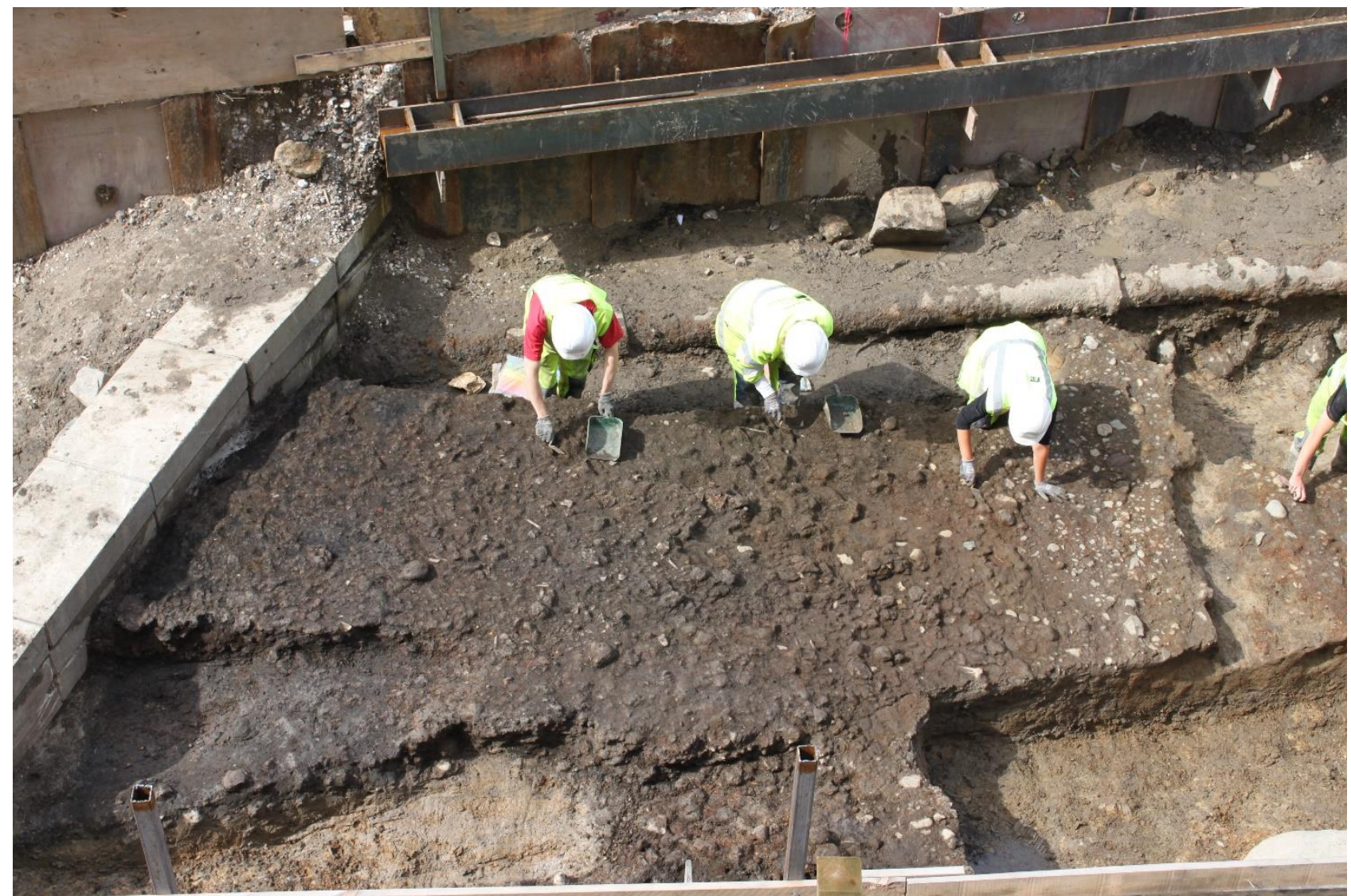

Arkeologer rensar ett av de stora lagren med slagg som påträffades $i$ Vester Voldgade vid utgrävnignen på Rådhuspladsen 2011. Lagret tolkas som en vägbeläggning.

\section{Järnets nätverk och aktörer}

Sammantaget ger informationen om järnhantverket på Rådhuspladsen möjliga ledtrådar till stadens tidiga utveckling, inte minst ger det underlag till att diskutera vilka nätverksförbindelser och aktörer som varit drivande i verksamheten. Läget vid Öresund har varit optimalt för handel och transport av järnråvara från Skåne och omgivande landskap. Det är också en lämplig plats för bearbetning av järnråvaran som ankommer till Själland, för bruk både i Havn men säkert också för transport vidare till andra städer och landsbyer på Själland. På så vis kan Havn ha fungerat både som en transithamn, handelsplats och centrum för järnhantverket i denna del av Själland.

Järnet blev under medeltiden en än mer eftertraktad råvara än tidigare. Järnet var nödvändigt för det samhällsbygge som tog fart vid denna tid i Danmark. Tillkomsten av en lång rad städer medförde ett stort behov av byggnadsmaterial. Samma sak gällde det mycket stora antalet kyrkor som byggdes runt om i landet, främst under 1100-talet. Till detta kom införsel av nya jordbruksmetoder som krävde en ny typ av plog (av järn) samt mobilisering inför väpnade konflikter med behov av nya vapen.

Det är lätt att föreställa sig, att järnet blev en central resurs i samhället, och något som de styrande krafterna ville försäkra sig tillgång till. ${ }^{22}$ Från skriftliga källor vet vi att kyrkan var inblandad i järnutvinning, bland annat i de halländska skogarna vid Tvååker. Källor berättar om munkar som drev en järnmölla och organiserade primärsmide $\mathrm{i}$ anslutning till möllan. ${ }^{23}$ Arkeologiska utgrävningar vid Tvååker har visat att denna produktion var i mycket stor skala. ${ }^{24} \mathrm{Ett}$ annat 
vittnesmål om järnets roll för kyrkan är att det i källor nämns som in natura-betalning från biskop Absalon till en hög kyrklig tjänsteman. ${ }^{25}$

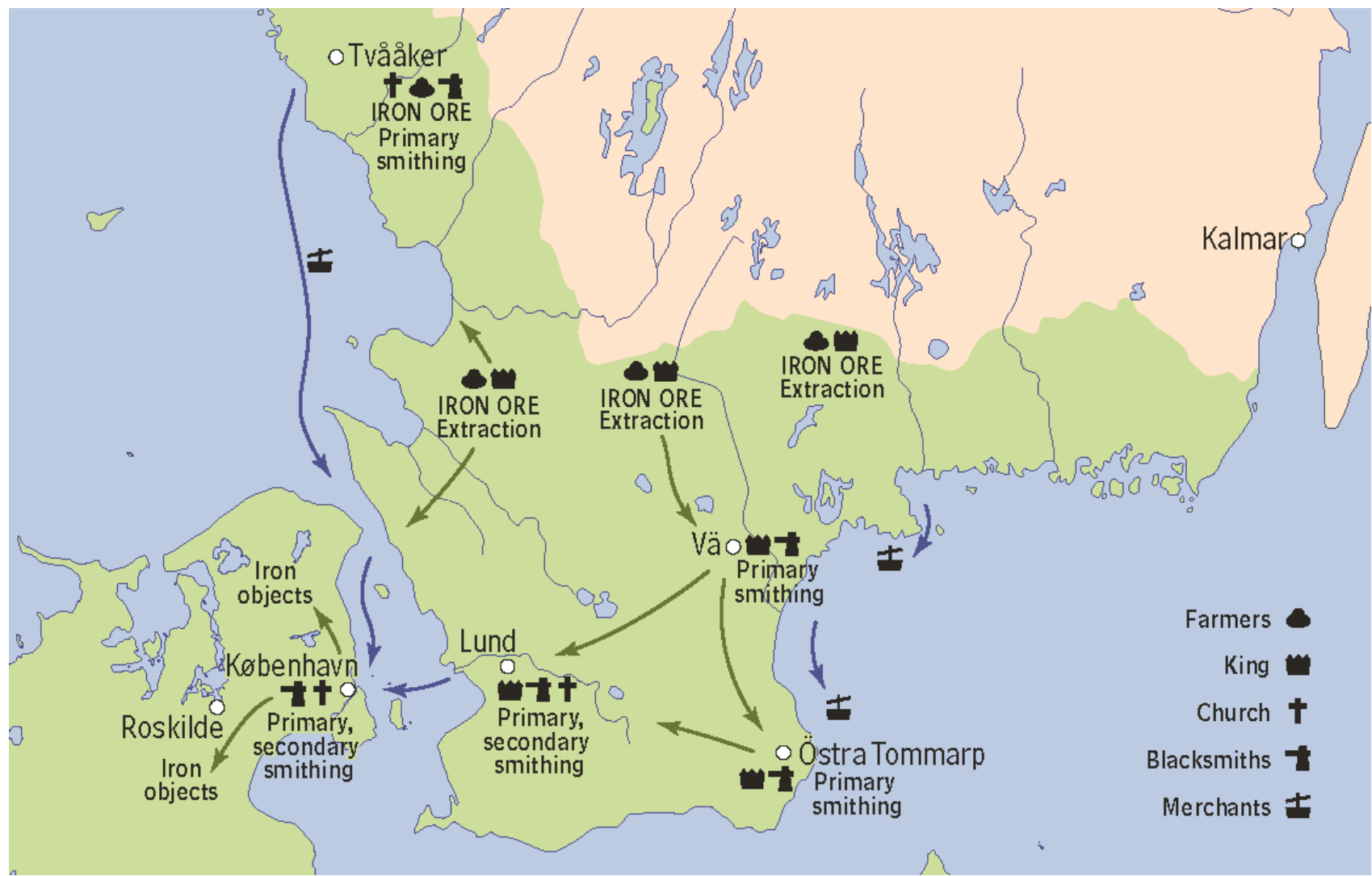

Karta som visar möjliga nätverksförbindelser och aktörer involverade i produktion, distribution och handel med järn $i$ de östra danska provinserna under tidig medeltid. Grafik: Bjørn Bachmann, Skalk

Även kungamakten var tidigt involverad i järnproduktion. I de tidiga skånska stadsbildningarna Vä, Tommarp och Lund, som alla var kunglig egendom (kungalev), har det gjorts storskaliga arkeologiska fynd av primärsmidesproduktion. ${ }^{26}$ Det finns också indikationer på kunglig inblandning redan i utvinningsprocessen. Det skogrika bälte som sträckte sig från Halland, över norra Skåne och till Blekinge var under tidig medeltid närmast obebodd. I skriftliga källor benämns området som "kongens ørken", med betydelsen att obebodd mark tillhörde kungen. ${ }^{27}$ I norra Skåne och Blekinge har det gjorts många arkeologiska fynd av småskaliga, lågteknologiska järnutvinningsplatser från samma period. ${ }^{28}$

Fynden överensstämmer med uppgifter om att bönder i området, så kallade skogsbönder, betalade skatt i form av järnråvara. ${ }^{29}$ Sammantaget ger informationen från arkeologiska och medeltida skriftliga källor ett möjligt scenario för Köpenhamns roll i ett östdanskt nätverk för järnproduktion, -distribution och handel - ett nätverk med många involverade aktörer från olika delar av samhället. ${ }^{30}$ Havn hade i detta sammanhang ett ideellt läge vid sundet, dit järn från de östliga danska provinserna kunde fraktas för vidare bearbetning, handel och distribution (se figur 5). Här fanns redan en samlingsplats för handel med agrara varor, samt goda hamnmöjligheter. Det fanns också sannolikt en form av central organisering av handeln, något som de två tidiga kyrkorna indikerar. 


\section{Framväxten av en urban miljö}

Det scenario som tecknats här innebär att Havn tidigt kan betraktas som ett centrum för handel, hantverk och distribution av varor. De relativt omfattande spåren av järnbearbetning på Rådhuspladsen pekar mot att kontakterna över sundet har varit viktiga. Detta skedde i en period när dessa perifera, men resursrika delar av danska riket fick ökad betydelse både politiskt och ekonomiskt. ${ }^{31}$ Platsens roll som hamn har medfört att den även varit viktig för resor över sundet. Inte minst uppkomsten av städerna Lund och Roskilde med dessas centrala kyrkliga funktioner, har krävt många resor däremellan, men det är troligt att resandet ökade även av andra orsaker under tidig medeltid.

Scenariot innebär också att det tidigmedeltida Havn bör betraktas som en tidig form av urban miljö. Havns primära funktion har inte varit agrar, även om det med stor sannolikhet bedrivits odling och djurhållning på platsen. Utifrån de samlade arkeologiska och historiska källorna om Havn och dess samtida samhällskontext, är det troligt att Havns funktioner varit som hamn, och handelsplats för lokala och regionala basvaror så som agrara produkter och järn.

De människor som bott här har sannolikt livnärt sig på handel, hantverk, transport och näringar kopplade till att ha besökande, till exempel värdshus. Bebyggelsen i 1000-talets Havn kan ha varit uppbyggd kring ett antal större gårdskomplex, med kopplingar till stormannafamiljer i omlandet. En sådan tidig fas ses till exempel i det tidigmedeltida Lund, och i Skänninge i Sverige. ${ }^{32}$ Man kan också föreställa sig en bebyggelse som växer fram längs den vägsträckning som löpte längs strandlinjen mellan dagens Rådhuspladsen och Kongens Nytorv.

De arkeologiska spåren av aktiviteter före 1200 är dock koncentrerade till den västra delen av denna sträckning, vilket innebär att det området varit centrum för det tidigmedeltida Havn. Under 1100talet ses i det arkeologiska materialet en intensifiering av aktiviteter i området mellan Rådhuspladsen och dagens Gammeltorv. Mot slutet av 1100-talet och i starten av 1200-talet sker stora satsningar på infrastruktur och kyrkliga institutioner, till exempel startar uppförandet av befästningen runt staden, med sina tre portar Vesterport, Nørreport och Østerport. Vor Frue kyrka, Nikolai kyrka och Gråbrödraklostret uppförs tidigt under 1200-talet. Dessa stora satsningar ska ses i samband med biskop Absalons övertagande av Havn, som skedde någon gång före 1167 (då han ska ha byggt borgen på Strandholmen) $)^{33}$.

Även om det tidiga Havn inte haft en framskjuten betydelse i det tidigmedeltida Danmark, har platsen haft en viktig roll som kommunikationspunkt. Dess kvaliteter har attraherat människor från olika samhällslager. Även om stora investeringar från samhällets maktelit varit viktiga för stadens fortsatta utveckling, har stadens förmåga att skapa goda försörjningsmöjligheter för en bred befolkningsbas varit avgörande för den framgång och tillväxt som Köpenhamn åtnjöt under medeltidens senare del och därefter.

\section{Summary}

Recent archaeological excavations around present-day City Hall Square in central Copenhagen has revealed ground-breaking information about the oldest phase of the town's history. The findings of a cemetery from the $11^{\text {th }}$ century, unknown from written sources and placed outside the later, fortified medieval town, is a "game changer" for our understanding of what, and who were behind the formation and early development of the town. At the City Hall Square were also found quite large scale remains of workshops involved in black-smithing, dating to the late $11^{\text {th }}$ to early $14^{\text {th }}$ 
century. The findings contribute with valuable information about subsistence, but also of the geographical and actor-based networks of importance for the further development of the town.

\section{Litteratur:}

Andersson, H. 2015. What did blacksmiths do in Swedish towns? I: Hansen, G.; S. P. Ashby and I. Baug (eds.). Everyday products in the Middle Ages. Crafts, Consumption and the Individual in Northern Europe c. AD 800-1600. Oxford (Oxbow books), s. 287-299.Crawford, B. 2006. The Cult of Clement in Denmark, Historie. Jysk Selskab for Historie. Aarhus, s. 235-282.

DD = Diplomatarium Danicum, Vol. 1-5, 1938 ff. Köpenhamn.

Dahlström, H. 2019. Networks of iron: the role of black-smithing in medieval Copenhagen. I: Acta Archaeologica Vol. 90:2.

Dahlström, H. 2020. En verden til forskel? En diskussion af koncepterne "urban" og "rural" med eksempel fra bebyggelser i middelalderens østlige Danmark. I: Jespersen, M. \& Thelle, M. (red.). Land og by på tværs 1000-1800. Festskrift til Bjørn Poulsen. Aarhus, s. 283-312.

Dahlström, H., Poulsen, B., Olsen, J. 2018. From a port for traders to a town of merchants:

exploring the topography, activities and dynamics of early medieval Copenhagen. Danish Journal of Archaeology vol. 7, s. 69-116.

El-Sharnouby, H. \& Høst-Madsen, L. 2008. København - fra fiskeleje til middelalderlig købstad. I: H. Andersen, G. Hansen \& I. Øye (red.). De første 200 årene - nytt blikk på 27 skandinaviske middelalderbyer. Bergen, s. 147-154.

Enghoff, I. B. 2005. Fisk og fiskeri. I: Kristiansen, M. S. (red.) Tårnby. Gård og landsby gennem 1000 år. Jysk Arkæologisk selskab. Højbjerg, s. 469-478.

Enghoff, I. B. 2015. Rådhuspladsen, Z.M.K. 29/2013; KBM 3827. The animal bones.

Archaeoscience, vol. 7 2015. Natural History Museum of Denmark. University of Copenhagen. Appendix 1 i Lyne. E. \& Dahlström, H. 2015. Rådhuspladsen Excavation report. Opublicerad arkeologisk rapport. Københavns Museum.

Fabricius, H. 1999. Københavns topografiske udvikling indtil 1300. Aarbøger for Nordisk Oldkyndighed og Historie 1998. København.

Hedvall, R., Lindeblad, K. \& Menadner, H. 2013. Borgare, bröder och bönder. Arkeologiska perspektiv på Skänninges äldre historia. Riksantikvarieämbetet, Stockholm.

Jensen, Jane Jark \& Dahlström, Hanna 2009. Beretning for Skt. Clemens I og III. Udgravning af den nordlige del af kirkegården tilhørende den middelalderlige Skt. Clemens kirke, København februar til juli 2008. KBM 3621. Opublicerad arkeologisk rapport. Københavns Museum.

Jouttijärvi, A. 2014. Rådhuspladsen (KBM 3827) Overall report. Heimdal Archaeometry Report 149. Appendix 7 Metallurgical report. I: E. Lyne \& H. Dahlström 2015. Rådhuspladsen Excavation report. Opublicerad arkeologisk rapport. Københavns Museum.

Jørgensen, B. 2006. Stednavne i København og Københavns Amt. Sokkelund Herred.

Sjællandsdelen. Danmarks Stednavne vol. 25, Köpenhamn.

Kieffer-Olsen, J. 2018. Kirke og kirkestruktur i middelalderens Danmark. Serie: University of

Southern Denmark Studies in History and Social Sciences, vol. 577.

Kristensen, H. K. \& Poulsen, B. 2016. Danmarks byer i middelalderen. Aarhus.

Magnusson, G. 1986. Lågteknisk järnhantering I Jämtlands län. Jernkontorets Bergshistoriska Skriftserie Nr. 22. Stockholm.

Märcher, M. 2010. Fra Lund til Kirke Hyllinge i 1000-tallet. I: M. Andersen \& P. O. Nielsen (red.). Danefæ. Skatter fra den danske muld. Copenhagen, s. 202-205.

Nyborg, E. 2004. Kirke og sogn i højmiddelalderens by. I: (red.) S. B. Christensen.

Middelalderbyen. Danske bystudier I. Aarhus, s. 113-190. 
Skyum-Nielsen, N. 1994. Fruer og Vildmænd, I, Dansk Middelalderhistorie 1250-1340.

Köpenhamn.

Stiesdal, H. 1975. Absalons borg. I: K. Hvidt, S. Ellehøj \& O. Norn (red.). Christiansborg Slot, bd.

1. Köpenhamn.

Stafseth, T. Under utarbetande. Beretning Rådhuspladsen Nord KBM 4286. Københavns museum.

Strömberg, B. 2008. Det förlorade järnet. Dansk protoindustriell järnhantering.

(Riksantikvarieämbetet) Stockholm.

Ödman, A. 1995. Skånskt järn från malm till marknad. I: Olsson, S.-O. (red.). Medeltida danskt järn. Framställning av och handel med järn i Skåneland och Småland under medeltiden. Högskolan i Halmstad, Halmstad. S. 146-155.

Ödman, A. 1998. Northern Skåne - a resource area for medieval Denmark. I: Andersson, H.; Ersgård, L.; Svensson, E. (red.). Outland use in Preindustrial Europe. Lund studies in medieval archaeology 20. (Lund University) Lund. S. 204-218.

\section{Noter}

${ }^{1}$ Dahlström et. al. 2018

2 ibid

${ }^{3}$ Dahlström et. al. 2018

${ }^{4}$ DD 1. ser., vol. 3, nr. 137

5 Jørgensen 2006; Nationalmuseets arkiv

${ }^{6}$ Nyborg 2004, Kieffer-Olsen 2018

${ }^{7}$ Dahlström et. al. 2018

${ }^{8}$ Stafseth, kommande

${ }^{9}$ Dahlström et. al. 2018

${ }^{10}$ Jensen \& Dahlström 2009

${ }^{11}$ Jensen and Dahlström 2009, p. 56

${ }^{12}$ Märcher 2010, s. 203

${ }^{13}$ Crawford 2006

${ }^{14}$ Dahlström et. al. 2018

${ }^{15}$ Fabricius 1999; El-Sharnouby \& Høst-Madsen 2008

${ }^{16}$ Enghoff 2015

${ }^{17}$ Enghoff 2005

${ }^{18}$ Dahlström 2020

${ }^{19}$ Dahlström 2019

${ }^{20}$ Jouttijärvi 2015

${ }^{21}$ Andersson 2015

${ }^{22}$ Andersson 2015; Dahlström 2019

${ }^{23}$ DD. 1:3, 223; DD 1:4, 67

${ }^{24}$ Magnusson 1986, p. 55f

${ }^{25}$ Skyum-Nielsen 1962, s. $31 \mathrm{f}$

${ }^{26}$ Ödman 1995, p. 146ff

${ }^{27}$ Strömberg 2008; Ödman 1998

${ }^{28}$ Söderberg 1996; Ödman 1998

${ }^{29}$ Strömberg 2008

${ }^{30}$ Dahlström 2019

${ }^{31}$ Kristensen \&Poulsen 2016

${ }^{32}$ Hedvall et. al. 2013

${ }^{33}$ Stiesdal 1975 